\title{
O lobby na regulação da publicidade de alimentos da Agência Nacional de Vigilância Sanitária
}

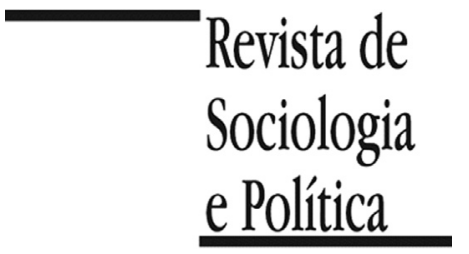

DOI 10.1590/1678-987316245706

\author{
Marcello Fragano Baird
}

\begin{abstract}
Resumo
O artigo analisa a ação política dos grupos de interesse empresariais ao longo do processo de regulação da publicidade de alimentos desencadeado pela Agência Nacional de Vigilância Sanitária (Anvisa) em 2005. Os objetivos principais são descrever as estratégias e articulações políticas desses grupos, de modo a aferir se sua ação foi bem-sucedida no sentido de minimizar ou anular a polêmica e conflituosa regulação proposta por aquela agência, cujos efeitos incidiam diretamente sobre as atividades do setor privado. O estudo compreendeu um acompanhamento detalhado de cada etapa do processo decisório, buscando observar quais arenas políticas são acionadas por esses grupos para a consecução de seus objetivos. Para a condução desta pesquisa, amparamo-nos no exame exaustivo de documentos relacionados à regulação proposta, oriundos dos três poderes, bem como dos grupos de interesse, e em entrevistas aprofundadas com os principais atores políticos envolvidos com a temática. A análise evidenciou que os grupos de interesse empresariais, refletindo seus amplos recursos políticos e econômicos, têm acesso às mais diversas arenas políticas, como a Anvisa, o Congresso Nacional, o Judiciário e a Advocacia-Geral da União, ator decisivo no desfecho do processo político aqui estudado. Também encontramos evidências de que a pressão do empresariado foi capaz de mitigar em grande medida a regulação da Anvisa, pois a norma foi alterada consideravelmente entre a consulta pública de 2006 e sua promulgação em 2010. Não obstante, pudemos observar que, a despeito do poder econômico incontrastável dos dois setores afetados, indústria de alimento e de publicidade, sua ação política não foi capaz de impedir a Anvisa de promulgar em 2010 uma versão mais branda do regulamento, o que nos sugere uma relativa autonomia política da agência. Por fim, alterações organizacionais e no comando da Anvisa em 2012, alinhadas aos interesses dos grupos empresariais, dão conta de mudanças mais profundas na agência, as quais parecem ter redefinido as próprias bases do relacionamento com o empresariado.
\end{abstract}

PALAVRAS-CHAVE: lobby; grupos de interesse; Anvisa; agências reguladoras; regulação da publicidade de alimentos.

Recebido em 17 de Agosto de 2014. Aceito em 23 de Janeiro de 2015.

\section{Introdução ${ }^{1}$}

\author{
1 Agradeço aos pareceristas \\ anônimos da Revista de \\ Sociologia e Política por seus \\ comentários.
}

\begin{abstract}
A s doenças crônicas não transmissíveis tornaram-se, possivelmente, o principal problema de saúde pública do século XXI. Dentre as medidas adotadas para enfrentar essa questão, a Agência Nacional de Vigilância Sanitária (Anvisa) propôs, em 2006, a regulação da publicidade de bebidas com baixo teor nutricional e de alimentos considerados potencialmente nocivos à saúde, por conterem quantidades elevadas de açúcar, gordura saturada, gordura trans e sódio.

Como seria de esperar, poderosos interesses econômicos mobilizaram-se para pressionar a Anvisa e outros atores estatais a frear a regulação posta em marcha. O objetivo principal deste trabalho é analisar o lobby dos grupos de interesse empresariais na regulação da publicidade de alimentos da Anvisa, percorrendo diversos momentos e arenas desse processo político até hoje. Entende-se por lobby qualquer ação política de defesa de interesses para influenciar decisões governamentais, o que inclui a produção de informações técnicas sobre um assunto, campanhas midiáticas e, principalmente, contatos diretos com atores estatais importantes.
\end{abstract}


A literatura que tratou da influência dos grupos de interesse na burocracia passou de modelos teóricos demasiadamente formais (Stigler 1975) a uma ênfase excessiva no papel das instituições, sem atentar para a ação efetiva dos grupos de interesse (Moe 1987). No Brasil, uma crescente literatura vem dando maior atenção ao papel da ação política dos grupos de interesse e à sua capacidade de influência. Grande parte desses estudos foca o Congresso Nacional (Taglialena \& Carvalho 2006; Cabral 2007; Mancuso 2007; Santos 2011).

Alinhado a esses outros estudos, este artigo busca alargar o rol de instituições contempladas, analisando também essa nova institucionalidade que são as agências reguladoras. A partir do exame da atuação no âmbito da Anvisa, analisaremos todas as arenas políticas relevantes acionadas pelos grupos de interesse para a consecução de seus objetivos, como o Congresso Nacional, outras instâncias do poder Executivo e o Judiciário. De forma mais específica, interessa-nos observar as estratégias levadas a cabo por esses grupos com vistas a identificar se, no fim do processo, o empresariado foi bem-sucedido em seu intento de barrar a regulação daquela agência.

Para a análise do processo decisório em torno dessa regulação, fizemos uso de metodologia qualitativa por meio de três ferramentas: pesquisa bibliográfica, pesquisa documental e pesquisa de campo por meio de entrevistas semiestruturadas. A pesquisa bibliográfica, focada no tratamento acadêmico dado ao lobby, permitiu situar o estudo teoricamente. A pesquisa documental possibilitou tanto a observação do processo político desencadeado pela regulação como o acompanhamento sistemático da ação dos grupos de interesse. Entre os documentos oficiais, destacam-se materiais elaborados pelo Ministério da Saúde e pela Anvisa, pareceres jurídicos da Advocacia-Geral da União (AGU) e decisões judiciais. No tocante à produção dos grupos de interesse, há livros, sites e blogs sobre o tema, abaixo-assinados e cartas de apoio ou crítica à regulação, assim como pareceres jurídicos contratados para influenciar as decisões. Matérias jornalísticas também compuseram o ferramental da pesquisa.

Por fim, as entrevistas semiestruturadas deram concretude à análise documental, permitindo a reconstituição dos elementos do processo decisório da maneira mais fidedigna possível. Partimos de um rol pré-determinado de questões, mas garantindo flexibilidade nas perguntas, conforme novas informações eram reveladas. As perguntas feitas aos entrevistados seguiram dois eixos básicos: (i) compreensão da estratégia de ação política dos grupos de interesse, com a identificação das principais arenas institucionais de atuação; (ii) percepção acerca dos resultados políticos alcançados como consequência da influência exercida.

A seleção dos entrevistados é fundamental, sendo que estes devem constituir-se em informantes-chave do processo estudado. O critério inicial para sua escolha esteve relacionado à participação nos mecanismos de participação da Anvisa, como a consulta pública e a audiência pública. A partir das entrevistas iniciais, potenciais novos informantes com ativa participação no processo eram indicados pelos entrevistados, num processo de "bola de neve". Mediante esse método, foram realizadas entrevistas com 24 atores estratégicos do governo, indústria e sociedade civil entre 22 de dezembro de 2011 e 2 de abril de 2012 . O Quadro 1 apresenta uma classificação das instituições entrevistadas por categoria a que pertencem.

\section{Grupos de interesse e burocracia}

O primeiro arcabouço teórico a tratar da relação entre grupos de interesse e burocracia, e em particular as agências reguladoras, foi a teoria da regulação 
Quadro 1 - Instituições entrevistadas

\begin{tabular}{lll}
\hline & Grupo de Informantes \\
\hline Governo & Executivo & Anvisa \\
& Legislativo & Ministério da Saúde \\
Sociedade Civil & Setor Regulado & ABIA (Associação Brasileira das Indústrias da Alimentação) \\
& & ABIR (Associação Brasileira da Indústria de Refrigerantes e Bebidas \\
& Não Alcoólicas) \\
& CONAR (Conselho Nacional de Autorregulamentação Publicitária) \\
& Grupos de Interesse Público & Instituto Alana \\
& IDEC (Instituto Brasileiro de Defesa do Consumidor) \\
& USP (Universidade de São Paulo) \\
& UnB (Universidade de Brasília) \\
\hline
\end{tabular}

Fonte: O autor.

${ }^{2}$ No original em inglês: "as a rule, regulation is acquired by the industry and is designed and operated primarily for its benefit". econômica, ou teoria da captura, formulada por George Stigler. Essa teoria aponta para a possibilidade de a regulação atender aos interesses da indústria em detrimento dos interesses do consumidor, caracterizando, dessa forma, a captura. A tese básica do autor é que "via de regra, a regulação é adquirida pela indústria, sendo elaborada e implementada para beneficiá-la" (Stigler 1975, p.114) $)^{2}$.

A teoria postula um sistema por meio do qual as indústrias demandariam regulação e os políticos, por sua vez, ofertariam essa regulação. A relação funcionaria da seguinte forma: os partidos políticos têm altos custos de operação para manter a máquina partidária funcionando, de modo que necessitam de dois tipos de recursos: auxílio financeiro e votos. As indústrias, por sua vez, necessitam da regulação para obter benefícios advindos do governo. A partir dessa relação de oferta e demanda, estrutura-se um sistema em que as indústrias financiam os políticos, garantindo sua sobrevivência, enquanto estes, em troca, disponibilizam a regulação econômica, assegurando toda sorte de benefícios às empresas.

Cabe destacar, sucintamente, uma importante contribuição feita à teoria da regulação econômica, que é o modelo de "rent extraction", formulado por McChesney (1997). Segundo essa abordagem, o financiamento aos políticos realizado pelas indústrias não ocorreria para a obtenção de regulação, mas sim para evitar que regulações onerosas sejam impostas. Como o governo tem a faculdade legal de tributar e regular, os políticos podem extrair rendimentos dos grupos privados. Nesse sentido, o financiamento privado também pode ter a função de evitar intervenções prejudiciais ao setor regulado.

Uma das críticas às abordagens econômicas da regulação diz respeito à sua abordagem teórico-formal, que não dá conta de compreender a atuação concreta dos grupos de interesse. Mas a principal limitação dessa teoria refere-se ao pouco espaço reservado às variáveis políticas dentro de sua estrutura analítica. Assim, a teoria da captura tinha como foco exclusivo a avaliação de resultados, em detrimento de uma abordagem mais ampla que englobasse a relação entre os diversos atores governamentais e também os mecanismos político-institucionais que moldam e determinam os resultados políticos.

Essas críticas ensejaram o surgimento, no âmbito da Ciência Política, do neoinstitucionalismo, cujo foco principal recai na questão do controle político. A falta de uma tradução política para os interesses dos grupos sociais foi 
${ }^{3}$ No original em inglês: "the mechanism by which voters' concerns are transformed by the political process into policy. In doing so, it fills an important gap left by both public-interest and capture theory". suprida, portanto, por uma literatura que buscava dar conta de entender "o mecanismo pelo qual as preocupações dos eleitores são transformadas pelo processo político em políticas públicas. Ao fazer isso, uma importante lacuna deixada pelas teorias do interesse público e da captura foi completada" (Levine $\&$ Forrence 1990, p.170) ${ }^{3}$.

Sob esse enfoque, as instituições, entendidas aqui como as regras do jogo, determinam e traduzem, ao cabo, os interesses de grupos sociais em políticas públicas. Nesse sentido, a eficácia de qualquer ator político no estabelecimento de regras para a supervisão de outros entes estatais determina vencedores e perdedores em uma dada política pública, o que justifica a atenção teórica ao controle político. De acordo com Moe (1987), esse esforço teórico perscruta a "caixa preta" dos economistas e evidencia as relações entre sistema político e burocracia, por meio das quais os interesses são traduzidos em políticas públicas.

A teoria neoinstitucionalista ancorou-se no problema do agente-principal, que trata da situação em que há assimetria de informação entre dois atores, o que significa que o "agente", a quem se encarrega de executar determinada ação, detém, por conta da proximidade com a tarefa a ser realizada, mais informações que o "principal", a autoridade em questão, possui. Hierarquicamente superior ao "agente", o "principal" busca, desta forma, monitorá-lo, de forma a exercer controle sobre suas ações. De acordo com Levine e Forrence (idem), essa teoria focaliza os mecanismos de supervisão, não se preocupando em prever resultados políticos.

A literatura neoinstitucionalista, de raiz norte-americana, iniciou seus estudos focando a relação entre o Congresso e as agências, buscando compreender por que aquele delega poderes a estas e de que maneira se dá o controle sobre as atividades dessas mesmas agências. A maneira mais simples de o Legislativo controlar as agências é aprovar leis detalhando ao máximo seu conteúdo, de modo a deixar pouco espaço para a regulamentação feita por burocratas das agências (Kerwin 1996). Outros expedientes utilizados para monitorar as agências incluem o controle por meio de corte orçamentário e dos comitês legislativos que supervisionam áreas específicas de políticas públicas, bem como a imposição de procedimentos administrativos.

Há, de maneira geral, dois mecanismos básicos pelos quais o congressista pode controlar a agência. O primeiro, chamado de "patrulha de polícia", consiste num acompanhamento sistemático das ações dos burocratas para avaliar se não estão em conflito com as preferências dos legisladores. O segundo, chamado de "alarme de incêndio", caracteriza-se como uma reação do Congresso a um alerta específico trazido à tona pelos grupos de interesse e cidadãos que tiveram suas preferências confrontadas pelos burocratas (McCubbins \& Schwartz 1984).

A literatura também dirigiu sua atenção a outros "principais", a saber, o presidente e o poder Judiciário. No primeiro caso, os meios de que dispõe o chefe do Executivo para controlar as agências são, principalmente, a prerrogativa de indicar a chefia dessas agências e a capacidade de definir a agenda política das burocracias. No caso do Judiciário, esse poder começou a ganhar importância, pois suas decisões sobre a constitucionalidade dos regulamentos passaram a ter impacto significativo sobre as ações dos burocratas.

Pode-se afirmar, assim, que o neoinstitucionalismo trouxe importante contribuição ao debate, ao mostrar que as instituições e suas regras também afetam a definição de quem serão os ganhadores na disputa política. Essa corrente, no entanto, acabou por focar demasiadamente as mediações institucionais. Não é que os autores dessa linhagem teórica desconsiderem o papel dos grupos de 
interesse, mas sua ação acaba por se traduzir em políticas públicas de modo muito indireto, diluído, de tal forma que esses interesses acabam sublimados em meio à ação de atores políticos operando no interior das instituições estatais.

Isso significou, tanto do ponto de vista teórico como empírico, uma grande desatenção à ação política e à influência dos grupos de interesse, peças fundamentais no jogo político regulatório. Embora os interesses sociais sejam representados, de uma forma ou de outra, pelos atores políticos que interagem no âmbito das instituições, como o Congresso Nacional e o Executivo com sua burocracia e agências, é fundamental que se traga a lume quais grupos são esses e se explicite como atuam politicamente acionando essas instituições em defesa de seus interesses. Quem pontuou essa questão mais cristalinamente foi Kerwin (1996), que, ao analisar a teoria do agente-principal, afirmou que:

"[...] os grupos de interesse nunca são considerados os principais, mas influenciam profundamente essas outras instituições. Suas ações estimulam e por vezes motivam as do Congresso, da Casa Branca e dos tribunais. Quando ameaçados pela ação ou inação dos burocratas, os grupos de interesse vão ao Congresso e à Casa Branca pedir ajuda" (idem, p.297).

\section{II.1. Grupos de interesse e consultas públicas}

Surgiu nos Estados Unidos, recentemente, uma nova e promissora literatura, buscando dar maior ênfase ao papel dos grupos de interesse em seu lobby junto às agências governamentais. Tais estudos valeram-se da existência de um mecanismo formal aberto à participação dos grupos de interesse, as consultas públicas, que eram negligenciadas pelas análises da Ciência Política. Em realidade, essa relativa desatenção à atuação dos grupos de interesse junto à burocracia é particularmente surpreendente naquele país, na medida em que um papel formal para sua participação na formulação de regras das agências estava previsto desde 1946 com a edição do Administrative Procedure Act - APA (Baumgartner \& Leech 1998).

De todo modo, foi justamente esse o caminho trilhado por diversos autores, a partir do final da década de 1990, que buscaram aferir a influência dos grupos de interesse nas decisões das agências por meio da observação da incorporação ou não das sugestões feitas por esses grupos às resoluções propostas durante as consultas públicas (Balla 1998; Golden 1998; West 2004; Yackee 2005; Naughton et al., 2007; Nelson \& Yackee 2012).

A literatura sobre agências no Brasil é bastante recente, tendo acompanhado a evolução institucional do país, que criou suas primeiras agências reguladoras na década de 1990. Com a novidade institucional, vários estudos focaram a formação das agências, observando as tramitações no Congresso Nacional e o debate político no interior do Executivo, que capitaneou todo esse processo (Piovesan 2002; Nunes et al., 2007; Baird 2011). Outros ainda buscaram compreender o significado institucional da criação das agências no âmbito da arquitetura político-institucional do país, identificando mudanças e continuidades (Cruz 2007; Ramalho 2007; Gomide 2011). O desenho institucional das agências também foi tema recorrente, especialmente para aqueles preocupados com accountability e os mecanismos de participação (Pó 2004; Pacheco 2006; Pó \& Abrucio 2006). Mas talvez o principal esforço empreendido pela academia brasileira tenha sido no sentido de compreender por que delegar poderes a burocratas não eleitos, que não poderiam ser exonerados imotivadamente, e as questões daí decorrentes, como autonomia e credibilidade (Melo 2002; Correa et al., 2006; Pavão 2008).

Estudos mais recentes, no entanto, têm seguido a mesma linha das pesquisas norte-americanas, buscando compreender a participação dos grupos de interes- 


\footnotetext{
${ }^{4}$ No original em inglês: "The entire sequence of decision-making - notice, comment, deliberation, collection of evidence, and construction of a record in favor of a chosen action afford[s] numerous opportunities for political principals to respond when an agency seeks to move in a direction that officials do not like".
}

se nas consultas públicas e a influência daí resultante (Mattos 2004; Alves 2008; Silva 2012; Baird \& Fernandes 2014).

Cabe destacar que a literatura neoinstitucionalista também considera os mecanismos de participação das agências governamentais. No entanto, as perguntas que quer ver respondidas são outras - neste caso, sua indagação remete ao controle político. A teoria está menos voltada para o papel e a influência exercidos pelos grupos de interesse, e mais interessada em compreender como os procedimentos administrativos, tais quais as consultas públicas, são usados como meio de frear a discricionariedade burocrática. Esses mecanismos serviriam como uma forma de os grupos de interesse controlarem a burocracia indiretamente, sinalizando ao Congresso e ao presidente que seus interesses estão sendo afetados. Nas palavras de McCubbins, Noll \& Weingast (1987, p.258):

“[...] toda a sequência do processo decisório - publicação de proposta de norma, comentários, deliberação, coleta de subsídios e justificativa da decisão - oferece inúmeras oportunidades para os "principais" políticos agirem caso uma agência tome medidas contrárias aos interesses das autoridades"4

Essa nova literatura representou, sem dúvida, um importante avanço na Ciência Política, na medida em que deu maior ênfase à atuação dos grupos de interesse. Além disso, sua metodologia aportou ganhos em termos de objetividade. O problema desse tipo de estudo, no entanto, é a desatenção às variáveis contextuais que podem explicar a razão efetiva das alterações feitas na versão final das resoluções (West 2005). Ao observar apenas um momento do processo decisório, as consultas públicas, tais estudos tampouco levam em conta o papel que outras instituições, acionadas por diferentes estratégias dos grupos de interesse, podem ter nas decisões de políticas públicas.

Nesse sentido, essa nova literatura, que trouxe importantes avanços teóricos e empíricos em relação à teoria da regulação econômica, acabou por esbarrar em limitações similares às encontradas por aquela abordagem, qual seja, uma desatenção em relação ao papel de outros atores e arenas políticas na definição das políticas públicas.

Nesse cenário, análises empíricas que levem em conta a relação entre os grupos de interesse e as diversas arenas políticas de forma abrangente, à maneira dos estudos de policy subsystems (Fritschler 1969; Heclo 1978), podem ser de grande valia. Neste artigo, objetivamos, por um lado, recuperar a importante contribuição das teorias econômicas da regulação ao enfatizar a ação dos grupos de interesse para a obtenção da regulação desejada. Por outro lado, não nos furtaremos a incorporar os ensinamentos da teoria neoinstitucionalista, atentando para a autonomia burocrática da Anvisa e o possível controle exercido por outros atores institucionais, como outros órgãos do Executivo federal, o Congresso Nacional e o poder Judiciário, acionados pelos grupos de interesse, de modo a alcançar a tradução política mais fiel possível do jogo político por trás dessa resolução.

\section{Contextualizando o embate político}

Nesta seção nos voltaremos para os antecedentes do tema, que motivaram a Anvisa a tomar medidas nessa área, bem como as iniciativas anteriores da agência no sentido de regular a publicidade. Além disso, descreveremos os principais grupos de interesse empresariais envolvidos no tema.

Antes, porém, vale destacar brevemente o status da Anvisa como agência reguladora, no âmbito da administração pública federal. A Anvisa é uma autarquia especial sem subordinação hierárquica, embora vinculada formalmente ao Ministério da Saúde, e que goza de grande autonomia política, 
financeira e gerencial. Seus diretores têm mandatos fixos não coincidentes com o do Presidente da República e não podem ser demitidos injustificadamente. A agência tem orçamento e quadro de pessoal próprios e pode emitir normas de acordo com sua competência, sendo a última instância de recurso em âmbito administrativo. Essas características dão grande poder à Anvisa, que define sua agenda e implementa normas ao setor regulado à revelia de ministérios ou do poder Legislativo, só podendo ser interpelada em âmbito judicial.

\section{III.1. O problema das doenças crônicas não transmissíveis}

A intenção da Anvisa de regular a publicidade de alimentos baseou-se em diagnósticos e recomendações nacionais e internacionais referentes ao aumento da incidência de doenças crônicas não transmissíveis (DCNT), como diabetes, doenças do coração, pressão alta e, principalmente, obesidade. Em 2001, de acordo com relatório da Organização Mundial da Saúde (OMS), esse tipo de doença foi responsável por cerca de $60 \%$ do total das 56,5 milhões de mortes notificadas no mundo. No caso da obesidade, por exemplo, a OMS estimava que, em dez anos, essa doença passaria "a ser a principal causa de morte evitável em todo o mundo, superando o número de óbitos causados pelo cigarro" (OMS apud Brasil 2006a, p.1).

Os principais fatores de risco para essas doenças estão relacionados ao comportamento, como má alimentação, estilo de vida sedentário e baixo consumo de frutas, legumes e verduras. Nesse sentido, a prevenção das DCNT é perfeitamente factível com ações de promoção da saúde, como a educação para uma alimentação saudável, o fomento à produção de determinados tipos de alimentos, a disseminação de uma cultura de práticas esportivas e a promulgação de leis e regulamentos que incentivem a adoção de comportamentos saudáveis.

Os maus hábitos alimentares referem-se, hoje em dia, principalmente, ao consumo crescente e excessivo de alimentos considerados de baixo teor nutricional, como açúcar, sódio, gordura saturada e gordura trans. Esse padrão alimentar é fortemente estimulado pela publicidade, em particular aquela voltada ao público infanto-juvenil.

Uma pesquisa de 2006 sobre o perfil da publicidade de alimentos na televisão brasileira dividiu-os em quatro categorias e revelou que o grupo menos saudável, composto por "gorduras, óleos e doces", aparece em primeiro lugar na frequência de veiculação, com 57,8\% dos anúncios televisivos (Nascimento apud Brasil 2007). Outra pesquisa mostrou, partindo do monitoramento de 2.650 horas de quatro canais de televisão abertos e fechados, que $42 \%$ das 237 peças publicitárias observadas eram voltadas exclusivamente ao público infantil (OPSAN/UnB apud Brasil 2007).

Para se compreender o embate político que se seguiu em torno da iniciativa da agência, é importante, além de pontuar o panorama das doenças crônicas não transmissíveis, atentar para os poderosos interesses empresariais que seriam diretamente afetados.

III.2. As indústrias de publicidade e de alimentos

Ao propor regular a publicidade de alimentos, a Anvisa impactaria ao mesmo tempo dois setores poderosos na economia brasileira: a indústria de alimentos e a indústria de publicidade. No caso desta última, vale destacar que diversos setores seriam afetados, na medida em que a indústria da publicidade está assentada no tripé anunciantes, agências de publicidade e veículos de comunicação. Ao longo da disputa política, esse setor esteve representado, 
5 O Brasil não possui um órgão governamental exclusivamente investido de poder para regular a publicidade. Essa responsabilidade está a cargo do CONAR, organização não governamental fundada em 1980 e composta pelas entidades do mercado publicitário brasileiro, cuja missão é estabelecer parâmetros para o exercício da publicidade, fazendo recomendações e aplicando penalidades quando considerar cabível. principalmente, pelo Conselho Nacional de Autorregulamentação Publicitária $(\mathrm{CONAR})^{5}$.

O outro setor afetado, os anunciantes dos produtos, é a indústria de alimentos, cujo principal representante é a Associação Brasileira das Indústrias da Alimentação (ABIA). Trata-se de setor de destaque nacional, pois movimenta um décimo da economia, respondendo pelo emprego de mais de 1,5 milhão de pessoas. Tais números já são suficientes para mostrar que qualquer governo seria extremamente cauteloso ao impor medidas que pudessem afetar o setor. $\mathrm{O}$ Quadro 2 revela o peso dos setores de publicidade e de alimentos na economia brasileira.

Um desses atores, o CONAR, já estava envolvido há bastante tempo em disputas regulatórias no âmbito da Anvisa. É importante resgatar brevemente duas outras experiências de regulação da publicidade na Anvisa e os resultados alcançados, pois as incursões nessa seara e as dificuldades enfrentadas serviram de aprendizado institucional à agência e acabaram por conformar decisões futuras no processo de regulação da publicidade de alimentos.

\section{III.3. Experiências anteriores de regulação da publicidade pela Anvisa}

A primeira tentativa de regulação da propaganda na Anvisa ocorreu em 2005, quando a agência propôs um regulamento que restringia a publicidade de bebidas alcoólicas. Em 2007, a própria agência, juntamente com o CONAR, consultou a Advocacia-Geral da União (AGU) sobre a legalidade da possível resolução. O entendimento do órgão foi que tal resolução só teria respaldo legal mediante alteração de lei federal proposta por projeto de lei ou medida provisória. Diante desse cenário, a Anvisa decidiu recuar, não propondo nenhuma regulação.

Ainda em 2005, a Anvisa iniciou os trâmites para uma nova regulação da publicidade, desta feita no setor de medicamentos. Após longo processo, a agência publicou, no fim de 2008, uma resolução nesse sentido. Novamente provocada pelo CONAR, a AGU concedeu, em junho de 2009, poucos dias antes da entrada em vigor da norma, novo parecer favorável à indústria de publicidade, que, munida desse despacho, recorreu à Justiça, conseguindo diversas liminares contrárias ao regulamento.

Tendo traçado o contexto político da regulação da publicidade de alimentos, com as motivações da Anvisa, os atores envolvidos e as primeiras iniciativas na área realizadas pela agência, passamos agora ao lobby efetivamente empregado pelo empresariado para combater a regulação proposta pela Anvisa.

\section{Lobby e processo político da regulação da publicidade de alimentos}

Nesta seção analisaremos o processo político da regulação da publicidade de alimentos, focando as estratégias de lobby dos grupos de interesse empresariais

Quadro 2 - Indicadores Econômicos das Indústrias de Publicidade e de Alimentos

Indústria de Publicidade Indústria de Alimentos (2008) (2010)

\begin{tabular}{lcc}
\hline Faturamento & $\mathrm{R} \$ 21,4$ bilhões & $\mathrm{R} \$ 330$ bilhões \\
$\%$ PIB & $4 \%$ & $9 \%$ \\
$\mathrm{~N}^{\mathrm{o}}$ de empregados & $711 \mathrm{mil}$ & 1.5 milhão \\
\hline
\end{tabular}

Fontes: O autor, a partir de ABAP (2008), ABIA (2010) e Grupo de Mídia São Paulo (2011). 
e verificando se elas foram bem-sucedidas em seu intuito de minimizar ou anular a regulação proposta pela Anvisa. Para tanto, partiremos da consulta pública realizada na Anvisa para discutir o tema e acompanharemos como outras arenas e atores políticos foram acionados pelos grupos do setor regulado para garantir seus interesses.

IV.1. O início da regulação e a autorregulamentação como resposta à sociedade

O início das discussões sobre a regulação da publicidade de alimentos no âmbito da Anvisa data de março de 2005, quando um grupo de trabalho composto por 12 organizações foi instituído para discutir o tema e apresentar uma proposta de regulamento na área, conforme o Quadro 3 (Brasil 2005).

O empresariado mostrou-se insatisfeito desde o início com o rumo tomado pelas discussões no grupo de trabalho. Conforme indicam Furlong e Kerwin (2005), os grupos de interesse enxergam a formação de coalizões como o principal instrumento de lobby. Nesse sentido, o CONAR e a ABIA uniram forças para tentar frear a iniciativa da Anvisa. Sendo o tema bastante controverso, inclusive juridicamente, uma das primeiras ações realizadas conjuntamente foi a contratação de parecer jurídico de eminente advogado, professor da Universidade de São Paulo (USP), a respeito da constitucionalidade da regulação em gestação na Anvisa, da competência da agência para realizá-la e até mesmo da representatividade do grupo de trabalho, já que não havia paridade na participação.

Tendo em vista que essa ação não surtiu efeito e que os atritos iniciais tiveram origem justamente na Anvisa, seria de esperar que o setor privado atuasse também à margem da agência para atingir seus objetivos. Um primeiro movimento nesse sentido ocorreu em setembro de 2006, dois meses antes da expedição da minuta do regulamento na Consulta Pública $n^{\circ} 71$. Ciente de que a norma seria extremamente restritiva e contrária a seus interesses, o setor privado buscou antecipar-se à ação da Anvisa e sinalizar à sociedade que estava tomando medidas para lidar com o problema. Nesse sentido, o CONAR fez modificações no Código Brasileiro de Autorregulamentação Publicitária, fortalecendo a regulação da publicidade de alimentos e bebidas e aquela destinada a crianças e jovens.

Quadro 3 - Grupo de Trabalho Instituído pela RDC nº 73

\section{Nome da organização}

Anvisa - GPROP e Gerência-Geral de Alimentos (GGALI)

Associação Brasileira das Indústrias de Alimentos - ABIA

Câmara dos Deputados/Frente Parlamentar de Saúde

Coordenação-Geral de Política de Alimentação e Nutrição (CGPAN) - MS

Comissão de Assuntos Sociais do Senado (Consultoria Legislativa)

Conselho Federal de Nutricionistas - CFN

Conselho Nacional de Autorregulamentação Publicitária - CONAR

Departamento de Proteção e Defesa do Consumidor - DPDC/MJ

Instituto de Defesa do Consumidor - IDEC

Ministério da Agricultura - MAPA

Ministério Público Federal

Sociedade Brasileira de Pediatria - SBP

Fonte: Brasil (2005). 
As mudanças no Código não desmobilizaram a Anvisa, que elaborou uma minuta de regulação, a qual foi submetida a consulta pública em novembro de 2006. As consultas públicas referem-se à abertura de um período de tempo, geralmente prorrogável, durante o qual qualquer cidadão pode enviar contribuições escritas às propostas das agências reguladoras. Cabe destacar que essas contribuições não precisam ser acatadas pelas agências. As audiências públicas, por sua vez, dizem respeito a uma sessão presencial no qual alguns cidadãos e grupos, favoráveis e contrários à regulamentação proposta, expressam suas opiniões a respeito da mesma. Essa ação da Anvisa deu origem à Consulta Pública $\mathrm{n}^{\circ} 71$, que se estendeu até $1^{\circ}$ de abril de 2007. Tratava-se de uma proposta de

"Regulamento Técnico sobre oferta, propaganda, publicidade, informação e outras práticas correlatas cujo objeto fosse a divulgação ou promoção de alimentos com quantidades elevadas de açúcar, de gordura saturada, de gordura trans, de sódio e de bebidas com baixo teor nutricional, quaisquer que sejam as formas e meios de sua veiculação" (Brasil 2006b).

Pode-se dizer, grosso modo, que a regulação proposta pela Anvisa tinha quatro eixos básicos de disciplinamento da publicidade de alimentos. O primeiro referia-se à exigência de veiculação de advertências sobre os malefícios relacionados ao consumo excessivo dos alimentos alvo da resolução.

O segundo eixo referia-se ao conteúdo que poderia ser veiculado nas propagandas. A norma vetava, sobretudo, que a propaganda buscasse associar o alimento a algum aspecto saudável da alimentação. O terceiro pilar era destinado exclusivamente às crianças. Eixo mais severo do texto, estipulava os horários permitidos para a veiculação de comerciais para crianças na rádio e na televisão e vedava o uso de personagens do universo infantil.

O quarto eixo ia além da publicidade, vedando a distribuição de amostras grátis, cupons de desconto, patrocínio e outras atividades promocionais. Também proibia a propaganda em caso de patrocínio de eventos culturais ou esportivos.

A consulta pública foi o primeiro espaço em que efetivamente foi possível avaliar a dimensão e a intensidade com que os diversos interesses foram afetados. Foram 254 manifestações de 248 contribuintes, conforme o Quadro 4.

É possível observar que houve um equilíbrio relativo entre os diversos grupos que contribuíram para a proposta da Anvisa. Em que pese uma leve sobrerrepresentação do setor regulado, contrário à proposição, todos os grupos puderam dar sua contribuição à norma proposta pela Anvisa. A observação do Quadro 4, contudo, mascara, em alguma medida, a intensidade da participação

Quadro 4 - Distribuição dos participantes por segmento

\begin{tabular}{lcc}
\hline Segmento & Quantidade & \% \\
\hline Representantes do setor regulado & 80 & 32,26 \\
Pessoas físicas & 71 & 28,63 \\
Representantes da sociedade organizada, instituições & 62 & 25 \\
governamentais e de ensino & & \\
Instituições de combate ao câncer & 35 & 14.11 \\
Total & $\mathbf{2 4 8}$ & $\mathbf{1 0 0 \%}$ \\
\hline
\end{tabular}

Fonte: Brasil (2005). 
6 A Anvisa disponibiliza em seu site um documento de 379 páginas em que colige todas as contribuições realizadas durante o período da Consulta Pública n 71 (Brasil 2006b).

7 Como exemplo, o estudo de Alves (2008) analisou 11 resoluções da Anvisa e encontrou uma média de 195 contribuições.

\footnotetext{
8 O CONAR calcula ter utilizado 11 pareceres de renomados juristas brasileiros ao longo do processo.

9 Entrevista realizada em 13

de fevereiro de 2012 .
}

do setor regulado. Em realidade, as 254 manifestações referiam-se a um único documento enviado por algum grupo social. No entanto, cada documento pode conter uma série de sugestões, questionamentos, dúvidas e comentários, que podem ser designados, de forma geral, por contribuições. Assim, uma manifestação pode conter diversas contribuições. Tanto é assim que a Anvisa computa o recebimento de 789 contribuições $^{6}$ ao longo da consulta pública, número extremamente elevado ${ }^{7}$ que revela como os mais diversos grupos, favoráveis ou contrários à medida, foram mobilizados pelo tema.

A análise dessas 789 contribuições traz um padrão bastante claro de participação dos grupos sociais. As contribuições das pessoas físicas, em muito menor número, referiam-se, de maneira geral, a frases curtas de apoio à proposta da Anvisa, sem qualquer manifestação propositiva ou comentário de ordem técnica ou jurídica. Na categoria "representantes da sociedade organizada, instituições governamentais e instituições de ensino", as contribuições eram bastante mais densas que as das pessoas físicas, mas seu número ainda se mantinha relativamente pequeno em comparação às dos grupos do setor regulado.

O setor regulado, por sua vez, apresentou centenas de documentos elaborados e complexos criticando ponto a ponto a resolução, refletindo a diferença de recursos financeiros e organizacionais entre os grupos. $\mathrm{O}$ foco de ação dos grupos de interesse empresariais foi, desde sempre, a Anvisa, onde lhes é facultado amplo acesso aos mecanismos de participação e às instâncias decisórias. Assim, o objetivo principal desses grupos era apresentar uma forte contra-argumentação durante a elaboração da minuta do regulamento, de modo a desarmar a agência e abortar o processo ainda em seu estágio inicial. Daí o recurso a toda sorte de pareceres ${ }^{8}$. Um lobista da indústria resume bem o ponto ao responder sobre o fulcro de sua estratégia: "Esclarecimento, estafante esclarecimento técnico-científico do assunto que seja levantado, ou seja, estratégia de desgaste através de argumentação técnico-científica" ${ }^{\prime}$.

Vemos, assim, que questões altamente conflituosas engendram ativa participação da sociedade e, principalmente, dos grupos empresariais. O Quadro 5 mostra quais foram o teor e as principais linhas argumentativas das contribuições dos grupos de interesse durante a Consulta Pública n ${ }^{\circ} 71$.

Tendo em vista a centralidade do debate jurídico-legal, que definiu, em última instância, o desfecho da resolução posteriormente adotada pela Anvisa para regular a publicidade de alimentos, vale discutir brevemente os principais argumentos nessa seara.

O setor regulado apresentava como base de sua argumentação dois artigos da Constituição Federal. Inicialmente, apontava para o artigo 22, que determina que legislar sobre a propaganda comercial é competência privativa da União. Sendo assim, apenas o Congresso Nacional poderia legislar sobre o tema (Brasil 1988).

Mas o cerne do debate estava no artigo 220. Seu parágrafo quarto especifica os itens cuja publicidade estará sujeita à restrição legal (tabaco, bebidas alcoólicas, agrotóxicos, medicamentos e terapias), o que inviabilizaria a regulação da publicidade de outros produtos. O item mais controverso na Constituição Federal, no entanto, refere-se ao parágrafo terceiro desse mesmo artigo, que prevê, a partir da criação de lei federal, o estabelecimento de meios legais que auxiliem a pessoa a se defender de propagandas nocivas à saúde.

O argumento central do empresariado é que a Constituição Federal é clara ao afirmar que cabe à lei federal determinar qualquer ato de regulação, conforme o artigo 220. Assim, qualquer tentativa de regulação que não se desse por lei federal seria considerada inconstitucional, pois feriria a reserva legal da União. 


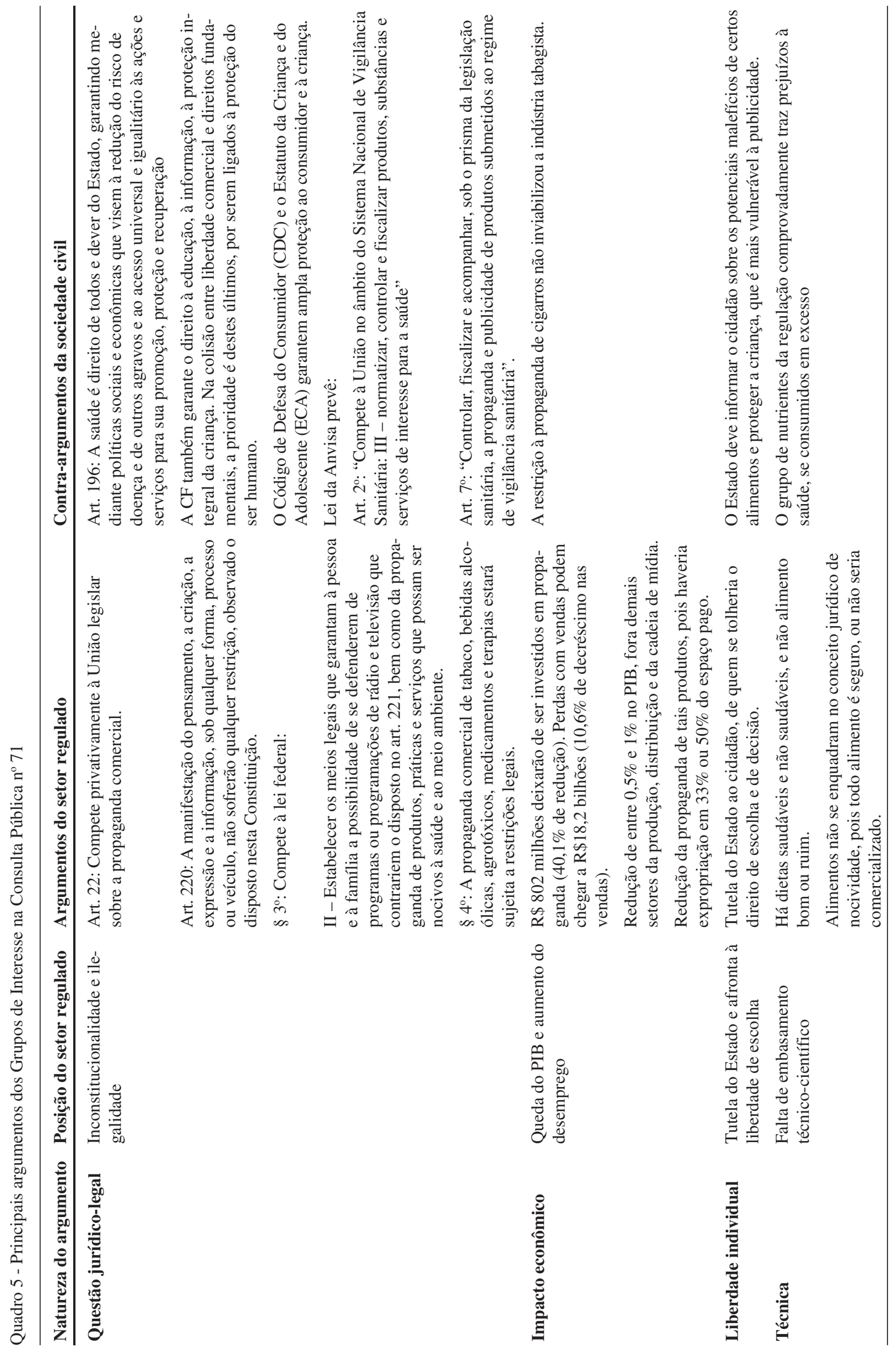




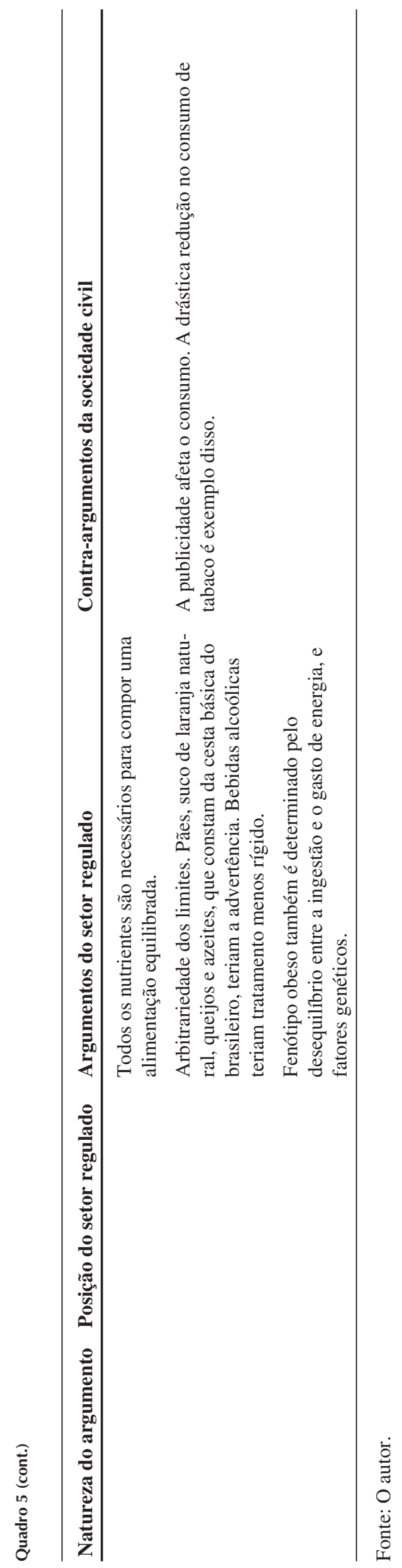


Grupos da sociedade civil, por sua vez, interpretam o artigo de outro modo. Eles entendem que o parágrafo terceiro do artigo 220 dá guarida a iniciativas para a proteção à saúde, desde que houvesse alguma lei nesse sentido, como o Código de Defesa do Consumidor e o Estatuto da Criança e do Adolescente. No caso do Código, seu artigo 37 proíbe a publicidade abusiva, que se refere àquela que "seja capaz de induzir o consumidor a se comportar de forma prejudicial ou perigosa à sua saúde ou segurança" (Brasil 1990). Argumenta-se que essa lei sustentaria a regulação da Anvisa, na medida em que a não prestação de informações relacionadas ao consumo dos nutrientes alvo do regulamento da agência constituiria publicidade abusiva.

Outro ponto controverso no debate diz respeito à legalidade da Anvisa para regular a propaganda de alimentos. A lei de criação da Anvisa estipula que a agência pode "controlar, fiscalizar e acompanhar, sob o prisma da legislação sanitária, a propaganda e publicidade de produtos submetidos ao regime de vigilância sanitária" (Brasil 2001). A indústria argumenta que a agência poderia exercer o controle e a fiscalização, mas não teria competência legal para expedir normas referentes a conteúdos publicitários, como se fosse legislador. De acordo com essa argumentação, nem se houvesse lei autorizando a regulação da publicidade de alimentos, como há para o tabaco e medicamentos, a Anvisa estaria legalmente investida para regulamentar a matéria, já que sua incumbência restringe-se ao controle, à fiscalização e ao acompanhamento da propaganda de alimentos (Ferraz 2006).

A sociedade civil, por sua vez, afirma que a lei de criação da Anvisa já garantiria a competência à agência. Em primeiro lugar, o artigo $2^{\circ}$ da lei afirma que "Compete à União no âmbito do Sistema Nacional de Vigilância Sanitária: III - normatizar, controlar e fiscalizar produtos, substâncias e serviços de interesse para a saúde" (Brasil 1999). Com base nesse trecho, argumenta-se que há garantias legais para que a agência possa normatizar. O outro trecho anteriormente citado apenas reforçaria a competência da Anvisa para tratar também de propaganda. Além disso, argumenta-se que a lei, ao criar a Anvisa, delegou a este órgão diversas atribuições, entre elas a regulação da publicidade, de modo que não seria necessária a aprovação de uma lei para tratar do assunto.

É possível observar que há argumentos sólidos dos dois lados do debate. De todo modo, como foi possível notar, a interpretação mais direta da Constituição Federal permitiria supor a necessidade de uma lei federal mais específica sobre o assunto. É o que defendem alguns juristas, bem como diversos juízes que decidiram sobre o tema. Ao mesmo tempo, porém, diversas sentenças encamparam a regulação da Anvisa, chamando a atenção para o grave problema de saúde no país decorrente das doenças crônicas não transmissíveis. Conclui-se, dessa forma, que a legislação abre espaço para todo tipo de interpretação, sendo possível, portanto, defender ou condenar juridicamente a regulação proposta pela Anvisa.

É importante afirmar, assim, que a consulta pública foi um instrumento de participação fortemente utilizado por todos os grupos de interesse, o que pode ser visto tanto pelo número de contribuições enviadas, como pela qualidade e esmero das mesmas. Isso revela que as agências reguladoras vêm adquirindo grande centralidade dentro do leque de ações dos grupos de interesse e que o instrumento da consulta pública é tido como um dispositivo relevante de participação para esses grupos.

Embora não haja, no Brasil, surveys que esmiúcem os métodos levados a cabo pelos grupos de interesse para o exercício de influência nas agências, as pesquisas feitas nos Estados Unidos por Furlong e Kerwin (2005) revelam que a provisão de comentários escritos às agências não só está entre os instrumentos mais utilizados pelos grupos ao tentar fazer valer seus interesses na formulação 
${ }^{10}$ Entrevista realizada em 13 de fevereiro de 2012. das regras, como também é considerado pelos próprios grupos como um dos métodos mais eficazes dentro de sua estratégia global.

A despeito da importância atribuída à participação nas consultas públicas, o empresariado sabia de antemão da dificuldade que teria para conseguir concessões da Anvisa nessa arena. Evidentemente, os grupos poderiam optar por não participar do processo, tentando deslegitimá-lo. No entanto, esse tipo de ação para esvaziar o papel da agência poderia ser contraproducente a esses mesmos grupos que queriam alterar a proposta da Anvisa, pois eles poderiam ser surpreendidos com ações futuras da agência, uma vez que não estariam acompanhando o processo. A seguinte frase de um representante do setor regulado resume bem o paradoxo enfrentado pela indústria: "É um jogo que você já sabe o resultado, mas você não pode deixar de participar porque aí você vai legitimar muito mais"10. Além disso, a tomada de posição dos grupos e a produção de informações para subsidiar esse processo também podem ser extremamente úteis em momentos posteriores do processo político.

Em relação ao papel das consultas públicas como instrumento metodológico para quantificar a influência dos grupos de interesse, é importante observar que, ao menos num caso conflituoso como esse, a análise quantitativa do impacto das contribuições no texto final não tem grande valia. Isso porque, no limite, não se trata de uma questão meramente técnica cuja resolução pressuponha ajustes marginais ao texto, mas sim de um embate político entre um grupo que defende a introdução da regulação estatal da publicidade de alimentos e outro que propugna a manutenção do status quo de autorregulamentação do setor.

Isso significa que os grupos empresariais atingidos pela regulação proposta tinham fortes incentivos para acionar outros atores políticos para que atuassem contra a norma. Conforme se verá a seguir, de fato, fatores políticos contextuais posteriores à consulta pública e alheios às contribuições realizadas durante a consulta pública concorreram para a ulterior mudança no texto final do regulamento. Não se trata de desqualificar a literatura que ancora suas análises da influência dos grupos de interesse nas consultas públicas, mas sim de problematizar a questão, revelando que outras estratégias e outros atores políticos acionados por esses grupos podem ser decisivos para a adequada compreensão da influência total exercida.

\section{IV.3. Ação junto aos poderes Executivo e Legislativo}

${ }^{11}$ Entrevista realizada em 13 de fevereiro de 2012.

${ }^{12}$ Entrevista realizada em 14
Se a ação junto à Anvisa não surtia efeito, o caminho natural seria buscar apoio junto a outros órgãos dos poderes Executivo e Legislativo. Conforme sentenciou um importante ator do empresariado: "Eu diria que o contato direto com atores estatais, num momento definitivo, é o fator agregado à estratégia de argumentação técnico-científica" ${ }^{11}$. O primeiro órgão político acionado foi o Ministério da Saúde, ao qual a Anvisa está administrativamente ligada. O CONAR e a ABIA foram recebidos algumas vezes pelo à época ministro, José Gomes Temporão. Tal contato não surtiu efeito, pois o ministro não intervinha nesse assunto, relegando à Anvisa a condução do tema.

A terceira frente natural de ação para o empresariado, além da própria Anvisa e de outros ministérios, era o Congresso Nacional, instituição mais plural e, certamente, mais receptiva aos interesses da indústria. Agregue-se a isso o fato de a argumentação mesma da indústria junto à Anvisa enveredar pela desqualificação da agência enquanto ente competente para regulamentar essa questão, afirmando, por outro lado, que o poder Legislativo, sim, seria o foro adequado para essa discussão. É sob esse ângulo que deve ser lida a seguinte frase de uma liderança do setor regulado: "a última linha de defesa é realmente o Congresso" $" 12$. 
de março de 2012

13 Baseado em relato da gerente-geral da Anvisa, Maria José Delgado. Entrevista realizada em 6 de fevereiro de 2012.
14 Transcrição da audiência pública realizada na Anvisa em 20 de agosto de 2009.
O objetivo central da ação empresarial era arregimentar os congressistas mais próximos em torno da questão e estimulá-los, sempre que possível, a pressionar diretamente a Anvisa, por exemplo, por meio da convocação de seus diretores. Angariar apoio parlamentar é importante por dois motivos. Por um lado, aumenta-se a pressão do lado opositor à norma da Anvisa. Por outro, cria-se um aliado que, embora não tenha poderes para interromper o processo desencadeado pela agência, pode buscar freá-lo mais adiante, caso a norma seja publicada.

\section{IV.4. A audiência pública e a grande virada}

O intenso jogo político em torno do tema e a enorme quantidade de contribuições feitas durante a Consulta Pública $n^{\circ} 71$ estenderam sobremaneira esse processo regulatório no âmbito da Anvisa, de tal forma que o estágio seguinte da tramitação na agência, a audiência pública, só foi ocorrer em 2009, quase dois anos e meio após o término da consulta pública.

Àquela altura, já estavam claras e cerradas as posições de todos os grupos, tendo sido a audiência pública o último momento de encontro entre os principais atores envolvidos nesse processo. $\mathrm{O}$ acirramento da disputa fazia-se notar inclusive fisicamente no auditório reservado à audiência, pois do lado esquerdo estavam os representantes do segmento produtivo, enquanto os grupos de interesse público postaram-se à direita de quem entra na sala ${ }^{13}$. Foi um acomodamento natural, que expressava perfeitamente a impossibilidade de qualquer concertação entre os grupos.

A audiência pública mantinha praticamente intocado o texto da resolução. Não à toa, o empresariado afastou-se da discussão sobre o regulamento e centrou seu discurso no questionamento à competência legal da Anvisa para regular a matéria. As palavras do presidente do ABIA, Edmundo Klotz, denotavam a posição da indústria e pressagiava o desfecho do caso:

\footnotetext{
"Se não atender os nossos interesses, nós procuraremos então aquele estado que estiverem os nossos interesses, não tem a menor dúvida. Se for o caso do Judiciário, perfeitamente; se não for, não. Não é uma ameaça, apenas o caminho natural das coisas dentro da democracia. Se estiver dentro daquilo que nós queremos, estamos todos de acordo, senão não"14
}

A grande mudança veio após a audiência, a portas fechadas, dentro da Anvisa. $\mathrm{O}$ vetor dessa mudança foi a Procuradoria interna da agência, ligada à AGU, que recomendou alterações de monta no texto original. É curioso notar que em duas ocasiões anteriores, ambas em 2007, a AGU e a Procuradoria da agência entenderam juridicamente corretos os procedimentos adotados pela agência para regular a publicidade de alimentos. No entanto, houve uma mudança nos quadros de chefia da Procuradoria na passagem de 2008 para 2009 , o que revelou ser um ponto de inflexão no processo, impactando decisivamente a versão final da resolução a ser publicada.

A nova Procuradoria da Anvisa reiterou, em novo parecer, a competência legal da agência para normatizar o tema, mas alterou drasticamente o texto do regulamento, pois entendia que a base jurídica para regular alimentos era menor que aquela para regular medicamentos. Um elemento novo ocorrido no processo determinou a cautela da Procuradoria: o já citado despacho da AGU em junho desse mesmo ano de 2009, que apontava pontos de inconstitucionalidade na resolução da agência que buscava regular a publicidade de medicamentos. Tanto é que, durante a audiência pública, o vice-presidente do CONAR, com o parecer da AGU em mãos, discutiu fortemente com o subprocurador-chefe da Anvisa, argumentando que o raciocínio para o caso de medicamentos também 
15 Entrevista realizada em 6 de fevereiro de 2012. era válido para alimentos, e que o chefe dele, o ministro da AGU, é quem endossava essa posição.

A adaptação da norma, promovida pela Procuradoria, foi no sentido de não atuar sobre práticas publicitárias em si, como os brindes, mas sim focar o fator saúde, reformulando o regulamento sob a óptica de defesa do consumidor, de modo que se informasse sobre o risco sanitário de certos produtos. Baseado nessas premissas, a versão final da resolução reforçava o primeiro eixo da proposta inicial, que eram os alertas sobre os perigos do consumo excessivo, ao mesmo tempo em que enfraquecia o segundo, mantendo apenas algumas restrições quanto ao conteúdo da informação e ao uso de figuras e símbolos. A parte de publicidade infantil, mais restritiva, foi praticamente abolida, restando um capítulo de um único parágrafo que apenas repete a necessidade de veiculação das advertências também nas propagandas destinadas às crianças. Por fim, o quarto eixo, relativo a amostras grátis, patrocínios e campanhas, foi integralmente suprimido. Como podemos ver, portanto, a versão final do regulamento, concluída em dezembro de 2009, foi fortemente modificada no sentido de tornar mais branda a regulação do setor privado.

A questão central é compreender por que a Anvisa alterou a norma na reta final, após ter conduzido todo o processo por cinco anos sob pressão, mas sem ceder aos interesses do setor regulado. Aparentemente, como argumenta o próprio governo, isso esteve relacionado à visão jurídica da nova Procuradoria da agência ${ }^{15}$. Mas mesmo essa cautela jurídica só pode ser explicada tendo em vista o quadro mais amplo da movimentação dos principais atores envolvidos no jogo. Assim, se a pressão política exercida diretamente sobre a Anvisa ao longo da tramitação da regulação não teve o efeito desejado, a ação contínua ao longo do tempo junto a outros órgãos do governo, a AGU nesse caso, parece ter trazido resultados no médio prazo. Pois se até a audiência a Anvisa pretendia manter o texto original do regulamento, a mobilização do empresariado nessa arena, fortalecido com a gestão bem-sucedida junto à AGU e sinalizando levar a agência mais uma vez à Justiça, acabou por determinar um recuo estratégico da Anvisa na questão.

Nesse sentido, pode-se afirmar que houve, por um lado, um aprendizado institucional da agência, que, tendo sua competência legal duas vezes posta em dúvida, preferiu ir adiante com um texto legal mais enxuto e palatável tanto juridicamente como aos interesses da indústria, o que poderia reduzir o atrito com o setor. Por outro lado, foi a pressão política do empresariado em todas as esferas governamentais, associada à ameaça de recurso à Justiça, que deu mostras da força desses grupos de interesse e catalisou o abrandamento da posição da Anvisa.

Por fim, é importante notar, retomando a discussão anterior, que, ao menos num caso polêmico como esse, uma análise que simplesmente coteje as versões final e inicial da resolução, sem atentar para as variáveis contextuais, como a pressão exercida em outros órgãos e intervenção da Procuradoria da Anvisa, estaria comprometida em seu intuito de compreender o impacto da atuação dos grupos de interesse na política regulatória. É nesse sentido que expedientes como entrevistas com burocratas envolvidos nas regulações podem ser úteis para descortinar as causas últimas nos processos decisórios.

IV.5. A RDC $n^{\circ} 24$ e um novo ator político: a $A G U$

Enquanto o governo discutia internamente essas alterações, o setor regulado uniu-se em nova ação para oferecer uma derradeira resposta à Anvisa e à sociedade em relação ao tema, com o propósito aparente de esvaziar a regulação da agência. Em 25 de agosto de 2009, cinco dias após a audiência pública, os 
${ }^{16}$ Entrevista realizada em 5 de março de 2012.

${ }^{17}$ Entrevista realizada em 17 de fevereiro de 2012.

${ }^{18} \mathrm{O}$ desconforto a respeito da relação entre o setor regulado presidentes da ABIA e da Associação Brasileira de Anunciantes (ABA) assinaram um Compromisso Público, adotado por 24 grandes empresas do setor alimentício, as quais se comprometiam a limitar a publicidade de alimentos e bebidas a crianças menores de 12 anos.

Após novas tentativas, por parte da Anvisa, de encontrar um texto que amainasse as resistências, a agência decidiu que não havia mais espaço para negociação e que, após mais de cinco anos de debates, era hora de concretizar e positivar o que havia sido discutido. Nesse sentido, a Anvisa publicou em 29 de junho de 2010 a Resolução da Diretoria Colegiada (RDC) $n^{\circ} 24$, primeiro regulamento específico para a publicidade de alimentos "abrangendo a divulgação e a promoção comercial de alimentos com elevadas quantidades de açúcar, de gordura saturada, de gordura trans, de sódio, e de bebidas com baixo teor nutricional" (Brasil 2010).

O setor regulado buscou responder à publicação da resolução com grande celeridade, dando curso a ampla mobilização. Já no dia 5 de julho, aproveitando-se da exitosa experiência anterior, o CONAR provocou novamente a AGU, comandada pelo ministro Luís Inácio Adams. No dia 7 de julho, um manifesto foi subscrito por 13 representantes da indústria de alimentos e de publicidade criticando a resolução expedida pela Anvisa. Ainda em julho, a força do setor de publicidade no Congresso tornou-se patente. Acionado pela Associação Brasileira das Agências de Publicidade (ABAP) e pela Associação Brasileira de Emissoras de Rádio e Televisão (ABERT), o deputado federal Milton Monti, do Partido da República (PR-SP), propôs o Projeto de Decreto Legislativo (PDC) $\mathrm{n}^{\circ} 2.830$, o qual tinha como único propósito sustar a aplicação da $\mathrm{RDC} \mathrm{n}^{\circ} 24$, por considerá-la inconstitucional ${ }^{16}$.

A resposta mais rápida às iniciativas do setor regulado, no entanto, veio da AGU, que em despacho de 7 de julho, acatou a posição do CONAR e recomendou a suspensão do ato normativo da Anvisa até decisão final por parte da Consultoria-Geral da União.

É importante fazer uma análise mais detida do papel da AGU, pois embora tenha sido acionada no fim do processo, revelou-se um ator importante no jogo político. Publicada a resolução, o setor publicitário reuniu-se para discutir a estratégia de atuação a partir desse momento. Convencidos da necessidade de entrar na Justiça, ponderaram, no entanto, que a profusão de processos acarretaria um desgaste muito grande ao poder Executivo, o que certamente não seria de seu interesse. Nesse sentido, segundo relato de representante do CONAR, começaram a conjecturar quais atores poderiam

"[...] evitar isso com autoridade jurídica, intelectual [?] O ministro da Justiça, a Casa Civil, e a Advocacia-Geral da União, que vai ter que ter esse trabalho, é ela que vai ter que representar, ela que vai ter que sustentar no Judiciário essa tese $[\ldots]$ quem sabe eles podem agir ainda" ${ }^{17}$

Um primeiro ponto interessante nessa ação política é o próprio acesso à AGU. A Advocacia-Geral da União, instituída por lei complementar em 1993, é o órgão encarregado de representar a União judicial e extrajudicialmente, além de ser responsável pelas atividades de consultoria e assessoramento jurídico do poder Executivo. Até mesmo pelas suas atribuições, é um órgão bastante voltado para dentro do próprio governo, atendendo aos diversos órgãos da administração e tendo pouca interface com a sociedade. Pelos relatos obtidos, foi durante a gestão do ministro José Antonio Dias Toffoli que as consultas externas, realizadas por grupos de interesse empresariais, ganharam maior notoriedade, tendo a AGU respondido duas vezes, como vimos, aos questionamentos do CONAR. Esse fato causou bastante estranheza e incômodo em vários setores do governo e da sociedade civil ${ }^{18}$, especialmente tendo-se em vista que o lobby junto à $\mathrm{AGU}$ foi bem-sucedido. 
e a AGU é direcionado, principalmente, ao ex-ministro Toffoli, que aprovou os dois pareceres contrários à Anvisa. Seu depoimento no livro do CONAR,

Autorregulamentação $e$ liberdade de expressão: a receita do CONAR, sobre as prerrogativas constitucionais da propaganda comercial só fez aumentar a desconfiança de grupos da sociedade civil.

19 Nota AGU/AV - 14/2007, de 5 de novembro de 2007 , assinada pelo consultor da União, Arthur Vidigal de Oliveira.
${ }^{20}$ Entrevista realizada em 14 de fevereiro de 2012.

21 É importante ter em mente que só a AGU pode defender a União no Supremo Tribunal Federal (STF). Nesse sentido,
Embora seja natural haver divergências de interpretação jurídica, mesmo entre procuradores do mesmo órgão, como foi o caso com a Procuradoria da Anvisa e a AGU, causou espécie também a alguns setores do governo o próprio despacho da AGU relativo à publicidade de alimentos. Muito mais brando que o anterior, de publicidade de medicamentos, que recomendava expressamente a revogação da resolução da Anvisa, o despacho relativo à RDC n ${ }^{\circ} 24$ afirmava não haver indícios de ilegalidade na norma, mas mesmo assim recomendava sua suspensão até o pronunciamento definitivo do órgão sobre o caso. O texto é, na verdade, bastante elogioso à resolução da Anvisa, inclusive tecendo comentários sobre os cuidados jurídicos que a agência teve ao elaborar a norma. $\mathrm{O}$ documento ainda evoca a legislação da Anvisa para afirmar que, em tese, a agência teria competência para legislar sobre o tema. No entanto, levanta dúvidas quanto à reserva legal da União para o estabelecimento de restrições à propaganda. Nesse sentido, é um despacho curioso, pois não apresenta, concretamente, óbices à normatização feita pela agência, mas mesmo assim prefere interromper sua aplicabilidade, ainda que temporariamente.

Outro ponto curioso é que a AGU já havia se manifestado a respeito do tema anteriormente, em 2007. À época, o despacho de um consultor da União aprovava a maneira como a Anvisa buscava regular o tema. Vale lembrar que a avaliação havia sido feita sobre o texto proposto na $\mathrm{CP} \mathrm{n}^{\circ} 71$, que era muito mais rígido que o da $\mathrm{RDC} \mathrm{n}^{\circ} 24$. O despacho de um consultor da União entendia "juridicamente corretos os procedimentos adotados pela Anvisa"19 para regular a publicidade de alimentos. Esse parecer, no entanto, só seria apreciado pelo à época advogado-geral da União, ministro Dias Toffoli, dois anos depois, em 2009. Ao analisar o texto, o ministro, que havia acabado de dar o parecer contrário à regulação da publicidade de medicamentos, preferiu não se posicionar. Em vez disso, solicitou à Anvisa que remetesse à AGU versão atualizada do regulamento para novo exame. Ao fazer isso, Toffoli, que sairia da AGU para assumir uma cadeira de ministro do Supremo Tribunal Federal ainda no final de 2009, relegava a decisão sobre a matéria a seu sucessor, ministro Luís Inácio Adams.

Por fim, outro ponto digno de nota é a não expedição de um parecer final da AGU a respeito da RDC $\mathrm{n}^{\circ} 24$ até hoje, o que contrasta com o andamento de outros itens igualmente polêmicos da pauta, como medicamentos, que já teve diversos pronunciamentos daquele órgão. A delicadeza política do tema parece ter se tornado um embaraço para a AGU.

Seja como for, o fato relevante é que, mesmo após as alterações feitas na resolução pelos procuradores da AGU lotados na Anvisa, o processo sofreu um revés na $\mathrm{AGU}$, o que fortaleceu sobremaneira o setor regulado, especialmente na próxima arena do embate político, o poder Judiciário. O despacho da AGU não só fundamentou as ações judiciais da indústria, como acabou por enfraquecer a própria agência, que se viu novamente questionada juridicamente a respeito de sua competência legal. Isso explica a crítica à AGU feita pelo diretor-presidente da Anvisa à época, Dirceu Raposo: “[...] me causava estranheza que a AGU, em algumas vezes, se manifestasse como órgão de consultoria privado. Ela serviu de órgão de consultoria para a indústria farmacêutica e órgão de consultoria para a indústria de alimento $^{20}$ ".

Para o empresariado, a ida à AGU revelou-se um tiro certeiro, pois ou a Anvisa seguiria a recomendação daquele órgão, o que barraria a implementação do ato, ou passaria por cima dele, mantendo a norma em vigor, mas correndo o risco de chegar fragilizada para a disputa judicial ${ }^{21}$. Assim como em relação à regulação da publicidade de medicamentos, a Anvisa não acatou a recomendação da AGU, de modo que a norma permanece em vigor até hoje, embora isso não tenha nenhum efeito na prática, como veremos. 
caso a AGU não mude sua posição, e a matéria chegue até a instância máxima do poder Judiciário brasileiro, a Anvisa estaria desprotegida judicialmente.

${ }^{22}$ Entrevista realizada em 23 de fevereiro de 2012.
A AGU surge, assim, como um ator extremamente importante nesse processo. De acordo com o primeiro diretor-presidente da Anvisa, Gonzalo Vecina Neto, cuja experiência à frente da agência foi de parca interlocução com aquele órgão, "a gestão da AGU era menos presente no dia a dia das organizações federais do que ela está sendo hoje ${ }^{22}$ ". Nesse sentido, parece que a AGU vem descobrindo seu papel e tornando-se crescentemente ativa na gestão governamental. Dadas a crescente judicialização dos assuntos e a possibilidade de ampla maleabilidade nas interpretações jurídicas, a tendência é que ela ganhe cada vez mais musculatura e se torne um lócus privilegiado de ação dos grupos de interesse. Dessa forma, é fundamental que se estude mais aprofundadamente a AGU, especialmente no que tange à sua democratização e interface com a sociedade.

IV.6. A judicialização da RDC $n^{\circ} 24 / 2010$

${ }^{23}$ Processo $\mathrm{n}^{\circ}$ 42882-45.2010.4.01.3400 impetrado pela ABIA contra a Anvisa.

\footnotetext{
${ }^{24}$ Disponível em ABIA (2010). Destaca-se que, em alguns segmentos, essa porcentagem pode chegar a $90 \%$.
}

Esgotadas todas as possibilidades de ação no âmbito dos poderes Legislativo e Executivo, não restava ao empresariado outra medida que não recorrer ao Poder Judiciário. Fortalecidas pelo despacho da AGU, as associações empresariais tinham, em certo sentido, respaldo do próprio governo para o embate jurídico.

Para os juízes, a resolução da Anvisa e o parecer da AGU sinalizavam uma indefinição do próprio governo em relação ao assunto. Afinal, havia, de um lado, uma agência buscando regular um tema e, ao mesmo tempo, o órgão de consultoria jurídica do Executivo, responsável por representar a União judicialmente e extrajudicialmente, afirmando que não era possível prosseguir com essa regulação. Diante desse impasse, seria até natural que os juízes, que conhecem pouco do tema, preferissem aguardar ao menos uma voz mais uníssona vinda do governo.

E foi exatamente o que aconteceu com diversos processos que tramitaram no poder Judiciário. A principal associação empresarial, ABIA, foi a primeira a impetrar uma ação contra a RDC $n^{\circ} 24$, alegando que não havia previsão legal na Constituição para a restrição que se queria criar (inconstitucionalidade) e que a Anvisa não teria competência legal para regular a matéria (ilegalidade). Do ponto de vista técnico, alegou, ainda, que "os parâmetros utilizados pela Anvisa não contam com fundamento científico"23. Como seria de se esperar, o parecer da AGU foi anexado ao processo judicial. E não apenas isso. Dada a iminência da entrada em vigor da norma (180 dias), a ABIA solicitou "pedido de antecipação dos efeitos da tutela", que equivale a uma liminar, de modo que a Anvisa ficasse impedida de aplicar a RDC n 24.

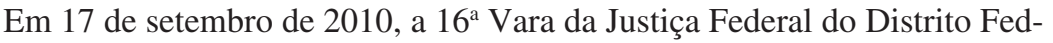
eral, destacando o parecer emitido pela AGU, deferiu o pedido de liminar da ABIA, suspendendo os efeitos da resolução para os seus associados, até que o mérito da questão seja julgado. Como a ABIA conta com mais de 1.500 associados diretos e filiados, representando cerca de $73 \%$ da produção de alimentos no Brasil ${ }^{24}$, essa liminar inviabilizou a aplicação da norma da Anvisa. Assim, essa primeira decisão judicial representou, na prática, o precoce fim da RDC n ${ }^{\circ} 24$, situação que permanece até hoje.

É interessante notar, nessa disputa judicial, que o lobby não se restringe aos tradicionais poderes Executivo e Legislativo, estendendo-se também ao Judiciário. Com vistas a influenciar o processo impetrado pela ABIA, o Instituto Brasileiro de Defesa do Consumidor (IDEC) e o Instituto Alana, favoráveis à regulação proposta pela Anvisa, protocolaram junto à Justiça Federal pedido de amicus curiae $^{25}$. O pedido foi aprovado e essas duas instituições passaram a fazer parte do processo, podendo contribuir com informações sobre o tema.
25 Trata-se de instituto introduzido pela Lei ${ }^{\circ}$ 
9.882/99 com vistas a pluralizar o debate em ações de grande impacto social. Esse instrumento permite a participação de terceiras partes que sejam representativas dos interesses gerais da coletividade de modo a qualificar e democratizar o debate (Brasil 1999).
${ }^{26}$ Frise-se que, até o momento, nenhum processo já transitou em julgado, ou seja, chegou a uma decisão definitiva em que recursos não são mais possíveis.
Trata-se de um instrumento importante, na medida em que os juízes entendem de leis, mas raramente têm acesso completo a todas as informações relevantes sobre o tema sob escrutínio.

Embora a ação da ABIA por si só já tenha sido suficiente para barrar a regulação da publicidade de alimentos proposta pela Anvisa, diversas outras associações entraram com ações semelhantes. É curioso notar, também, que algumas associações não diretamente ligadas à indústria de alimentos, como a Associação Nacional dos Restaurantes (ANR) e a Confederação Nacional do Turismo (CNTur), mobilizaram-se ou foram mobilizadas para acionar a justiça. Esse movimento amplo e intenso do empresariado gerou um total de 11 processos contra a Anvisa.

Dos 11 processos que estão correndo na Justiça, dez já tiveram decisão em primeira instância, sendo sete favoráveis à indústria e três favoráveis à Anvisa ${ }^{26}$. Em que pese o maior favorecimento à causa do setor regulado, destaca-se que a norma não é ponto pacífico no poder Judiciário. De maneira geral, quando os magistrados julgam procedentes as ações, decidindo, portanto, em favor da indústria, os argumentos de inconstitucionalidade e ilegalidade são aceitos. Nas ações favoráveis à Anvisa, os juízes costumam focar o grave problema de saúde que são as doenças crônicas não transmissíveis, afirmando que a regulação poderia ser feita pela agência, pois não caberia à lei chegar a esse nível de detalhamento.

\section{IV.7. Desdobramentos na Anvisa}

\footnotetext{
27 Entrevista realizada em 13 de fevereiro de 2012.

28 Entrevista realizada em 2 de abril de 2012.
}

\footnotetext{
${ }^{29}$ Entrevista realizada em 6 de fevereiro de 2012 .
}

O poder Judiciário não encerrou a disputa política, que voltou a ter a Anvisa como centro das atenções. A fragilização da agência veio não apenas com a judicialização da RDC $\mathrm{n}^{\circ} 24$, mas com mudanças mais profundas em suas instâncias decisórias máximas.

O empresariado estava extremamente insatisfeito com a agência, que teria sido politizada e estaria blindada pelo fato de o diretor-presidente no período da RDC n ${ }^{\circ} 24$ ser homem de confiança e ter o respaldo do presidente da Câmara dos Deputados à época, Arlindo Chinaglia, do Partido dos Trabalhadores (PT-SP). Nas palavras de um lobista da indústria: "A Anvisa não é um órgão técnico, a Anvisa é um órgão político, dominada por um partido político, e que atende a interesses políticos sob argumentação técnica, ponto"27.

De acordo com o relato ${ }^{28}$ de importante player do setor, durante a campanha presidencial de 2010, 156 empresários procuraram o comitê de campanha da então candidata Dilma Rousseff, do PT, para reclamar da atuação da Anvisa, que seria refratária ao empresariado. Teriam saído de lá com a promessa de que, se eleita, a presidente poria "ordem na casa". A nomeação do novo diretor da Anvisa, Jaime Cesar Oliveira, em 2011, seria o cumprimento desse acordo. Egresso da Casa Civil, que era chefiada por Dilma Rousseff, ele é visto como "o homem da Dilma" na Anvisa, e teria a função de estabelecer um novo canal de diálogo com o setor privado.

Na visão de uma funcionária da área de saúde do governo, maior diálogo com o setor privado representaria uma maior condescendência com o empresariado. A respeito do novo diretor, ela afirma que "ele tem uma posição contrária, totalmente contrária à [regulação da] publicidade [...] ele foi lá para dentro para conter isso [...] é um lobby explícito do Executivo controlando a Anvisa para não funcionar [...]"29.

A posição do novo diretor parece confirmar esse diagnóstico. Em sua visão, a Anvisa teria errado no cálculo político em torno da $\mathrm{RDC} \mathrm{n}^{\circ} 24$, de tal modo que o empresariado foi capaz de "fazer uma mobilização efetiva, coesa [...]", 
${ }^{30}$ Entrevista realizada em 6 de fevereiro de 2012.

${ }^{31}$ Entrevista realizada em 6 de fevereiro de 2012 .

\section{Conclusões}

32 Entrevista realizada em 13 de fevereiro de 2012. tendo sido, portanto, bem-sucedido em seu intento de sustar a norma. Diante desse cenário, a Anvisa estaria de "mãos atadas", não havendo "viabilidade na RDC" 30 . A agência, portanto, abriu mão de buscar meios próprios para regular a questão.

O retraimento da Anvisa está refletido também na própria organização da agência, pois uma reestruturação interna, por meio da Portaria n ${ }^{\circ} 422$, de 16 de março de 2012, desmembrou a Gerência-Geral de Propaganda, que passou a fazer parte de uma área mais ampla, a Gerência-Geral de Inspeção, Monitoramento da Qualidade, Controle e Fiscalização de Insumos, Medicamentos e Produtos, Propaganda e Publicidade (GGIMP) (Brasil 2012). Nesse processo, a área de política de publicidade foi enfraquecida, na medida em que não há mais uma gerência específica para o tema. O próprio diretor, sob o qual a nova gerência funcionará, mostrou-se preocupado com a "perda de accountability"31 da área, o que poderia ocasionar um esvaziamento dessa pauta.

Buscamos, neste trabalho, contribuir empiricamente com a crescente literatura brasileira que vem sendo desenvolvida para compreender a ação política dos grupos de interesse e sua capacidade de influenciar as políticas públicas. Ao descrever as diversas estratégias levadas a cabo pelos grupos de interesse empresariais, esperamos ter demonstrado a importância de se adotar uma visão sistêmica da atuação desses grupos, que acionam diferentes arenas e atores políticos com vistas a alcançar seus objetivos. Um olhar simplesmente voltado para um ponto específico do processo decisório não dá conta da complexidade do jogo político.

Na regulação da publicidade de alimentos proposta pela Anvisa, pudemos observar que o empresariado atuou fortemente na Anvisa, ao mesmo tempo em que buscava apoio de outros órgãos do poder Executivo e do Congresso Nacional. É importante notar, também, que, a partir da promulgação da norma pela Anvisa, a ação do empresariado foi mais incisiva e efetiva. É nesse contexto que ocorre a gestão bem-sucedida junto à Advocacia-Geral da União, que acabou sendo decisiva para inviabilizar, no poder Judiciário, a aplicação da $\mathrm{RDC}^{\circ} 24$. Esse novo ator político, que se mostrou decisivo na política pública em tela, certamente deve receber maior atenção dos estudiosos da área.

É interessante observar, assim, que a estratégia de lobby dos grupos de interesse empresariais passa pela exploração incessante de todos os canais políticos possíveis, aproveitando-se do acesso privilegiado facultado por seu amplo poder econômico. As ações em todas as frentes políticas possíveis reforçam sua influência e contribuem para aumentar as possibilidades de sucesso. As palavras de um lobista da indústria deixam claro esse ponto: "Se eu não tivesse participado do processo, lutado contra, feito tudo que fiz, não adiantaria eu ter ido à AGU no final, eu ia ser um desconhecido. A AGU só me reconheceu pelo capital que eu levei para ela mostrando quanto eu tinha" ${ }^{32}$.

O fato fundamental, no entanto, é que o empresariado foi bem-sucedido em suas ações, pois o regulamento, aprovado em 2010, não teve nenhum efeito prático até o momento. Ressaltamos, porém, que sua ação política não foi capaz de impedir a Anvisa de prosseguir com o regulamento proposto, o que nos sugere relativa autonomia política da agência. Não obstante, encontramos evidências de que a pressão do empresariado foi capaz de mitigar em grande medida a regulação da Anvisa, pois a norma foi alterada consideravelmente entre a consulta pública de 2006 e sua promulgação em 2010.

Por fim, cabe destacar que alterações organizacionais e no comando da Anvisa em 2012, alinhadas aos interesses dos grupos empresariais, dão conta de 
mudanças mais profundas na agência, as quais parecem ter redefinido as próprias bases do relacionamento com o empresariado. Sob essa óptica, o lobby do empresariado foi extremamente eficaz na reestruturação das relações com a Anvisa para o futuro, o que nos remete às dificuldades de equilibrar o jogo político na democracia diante do peso incontrastável do poder econômico.

Diante desse cenário, o mais provável é que os enfrentamentos políticos em torno da regulação da publicidade de alimentos não saudáveis ocorram não mais no âmbito da Anvisa, que foi enfraquecida em seu poder regulatório, mas no poder Legislativo, no qual também haverá forte resistência.

Marcello Fragano Baird (marcellofb @ hotmail.com) é Doutorando em Ciência Política pela Universidade de São Paulo (USP) e Professor do curso de Pós-Graduação da Escola do Parlamento da Câmara Municipal de São Paulo. Vínculo institucional: Universidade de São Paulo, São Paulo, SP, Brasil.

\section{Referências}

Alves, S.M.C., 2008. Processo de participação da sociedade civil nas consultas públicas realizadas pela Agência Nacional de Vigilância Sanitária - Anvisa (2000 - 2006). Dissertação de Mestrado. Brasília: Universidade de Brasília.

Baird, M.F., 2011. Gênese e constituição da Anvisa: o jogo político da política regulatória no setor de vigilância sanitária. In $X X X V$ EnANPAD. Rio de Janeiro.

Baird, M.F.; Fernandes, I., 2014. Flying in Clear Skies: Technical Arguments Influencing ANAC Regulations. Brazilian Political Science Review, 8(2), pp.70-92. DOI: 10.1590/1981-38212014000100012

Balla, S.J., 1998. Administrative Procedures and Political Control of the Bureaucracy. The American Political Science Review, 92(3), pp.663- 673. DOI: 10.2307/2585488

Baumgartner, F.R. \& Leech, B.L., 1998. Basic Interests: The Importance of Groups in Politics and in Political Science. Princeton: Princeton University Press.

Cabral, E., 2007. Articulação de interesses do empresariado industrial no processo de produção da regulação ambiental: convergências e divergências. Tese de Doutorado. Belo Horizonte: Universidade Federal de Minas Gerais.

Correa, P.; Pereira, C.; Mueller, B.; Melo, M., 2006. Regulatory Governance in Infrastructure Industries: Assessment and Measurement of Brazilian Regulators. Trends and Policy, 3. The World Bank. DOI: 10.1596/978-0-8213-6609-7

Cruz, V., 2007. Agências reguladoras: entre mudanças institucionais e legados políticos. Tese de Doutorado. Rio de Janeiro: Instituto Universitário de Pesquisas do Rio de Janeiro.

Ferraz, T.S., 2006. Parecer Jurídico a respeito da proposta de regulação da propaganda de alimentos da Agência Nacional de Vigilância Sanitária (Anvisa). Digit.

Fritschler, A.L., 1969. Smoking and Politics: Policymaking and the Federal Bureaucracy. Des Moines: Meredith Corporation.

Furlong, S.R.; Kerwin, C.M., 2005. Interest Group Participation in Rule Making: A Decade of Change. Journal of Public Administration Research and Theory, 15(3), pp.353-370. DOI: 10.1093/jopart/mui022

Golden, M.M., 1998. Interest Groups in the Rule-Making Process: Who Participates? Whose Voices Get Heard? Journal of Public Administration Research and Theory, 8(2), pp.245-270. DOI: 10.1093/oxfordjournals.jpart.a024380

Gomide, A.A., 2011. A política das reformas institucionais no Brasil: a reestruturação do setor de transportes. Tese de Doutorado. São Paulo: Fundação Getúlio Vargas.

Heclo, H., 1978. Issue Networks and the Executive Establishment. In A. King, ed. The New American Political System. Washington, D.C.: American Enterprise Institute.

Kerwin, C.M., 1996. Normatização: como entidades governamentais escrevem leis e fazem política. Rio de Janeiro: Nórdica.

Levine, M. \& Forrence, J., 1990. Regulatory Capture, Public Interest, and the Public Agenda: Toward a Synthesis. Journal of Law, Economics, \& Organization, 6 (special issue), pp.167-198. DOI: 10.1093/jleo/6.special_issue.167

Mancuso, W.P., 2007. O lobby da indústria no Congresso Nacional: empresariado e política no Brasil contemporâneo. São Paulo: Humanitas/Edusp.

Mattos, P., 2004. Regulação econômica e social e participação pública no Brasil. In V. Schattan; P. Coelho \& M. Nobre, eds. Participação e deliberação: teoria democrática e experiências institucionais no Brasil contemporâneo. São Paulo: Editora 34.

McChesney, F., 1997. Money for Nothing: Politicians, Rent Extraction, and Political Extortion. Cambridge, MA: Harvard University Press.

McCubbins, M. \& Schwartz, T., 1984. Congressional Oversight Overlooked: Police Patrols versus Fire Alarms. American Journal of Political Science, 28(1), pp.165-179. DOI: 10.2307/2110792

McCubbins, M.; Noll, R. \& Weingast, B., 1987. Administrative Procedures as Instruments of Political Control. Journal of Law, Economics, \& Organization, 3(2), pp.243-277.

Melo, M.A., 2002. As agências regulatórias: gênese, desenho institucional e governança. In F.L. Abrucio \& M.R. Loureiro, eds. O Estado numa era de reformas: os anos FHC. Brasília: SEGES-MP. 
Moe, T.M., 1987. Interests, Institutions, and Positive Theory: The Politics of the NLRB. Studies in American Political Development, 2, pp.236-299. DOI: 10.1017/S0898588X00001784

Naughton, K.; Schmid, C.; Yackee, S. \& Zhan, X., 2009. Understanding Commenter Influence During Agency Rule Development. Journal of Policy Analysis and Management, 28(2), pp.258-277. DOI: 10.1002/pam.20426

Nelson, D. \& Yackee, S.W., 2012. Lobbying Coalitions and Government Policy Change: An Analysis of Federal Agency Rulemaking. The Journal of Politics, 74(1), pp.1-15. DOI: 10.1017/S0022381611001599

Nunes, E.; Nogueira, A.; Costa, C.; Andrade, H. \& Ribeiro, L., 2007. Agências reguladoras e reforma do Estado no Brasil: inovação institucional e continuidade no sistema político-institucional. Rio de Janeiro: Garamond.

Pacheco, R.S., 2006. Regulação no Brasil: desenho das agências e formas de controle. Revista de Administração Pública, 40(4), pp.523-543. DOI: 10.1590/S0034-76122006000400002

Pavão, N.C., 2008. Instituições, credibilidade e governança regulatória no Brasil: um estudo de caso do desenho da regulação nos setores de telecomunicações e eletricidade. Dissertação de Mestrado. São Paulo: Universidade de São Paulo.

Piovesan, M.F., 2002. A construção política da Agência Nacional de Vigilância Sanitária. Dissertação de Mestrado. Rio de Janeiro: Fundação Oswaldo Cruz.

Pó, M.V. \& Abrucio, F.L., 2006. Desenho e funcionamento dos mecanismos de controle e accountability das agências reguladoras brasileiras: semelhanças e diferenças. Revista de Administração Pública, 40(4), pp.679-698. DOI: 10.1590/S0034-76122006000400009

Pó, M.V., 2004. A accountability no modelo regulatório brasileiro: gênese e indefinições (os casos da ANATEL e ANS). Dissertação de Mestrado. São Paulo: Fundação Getúlio Vargas.

Ramalho, P.I.S., 2007. A gramática política das agências reguladoras: comparação entre Brasil e EUA. Tese de Doutorado. Brasília: Universidade de Brasília.

Santos, M.L., 2011. O parlamento sob influência: o lobby da indústria na Câmara dos Deputados. Tese de Doutorado. Recife: Universidade Federal de Pernambuco.

Silva, M.B., 2012. Mecanismos de participação e atuação de grupos de interesse no processo regulatório brasileiro: o caso da Agência Nacional de Energia Elétrica (ANEEL). Revista de Administração Pública, 46(4), pp.969-992. DOI: 10.1590/S0034-76122012000400004

Stigler, G., 1975. The Theory of Economic Regulation. In The University of Chicago Press.

Taglialena, G.H.F. \& Carvalho, P.A.F., 2006. Atuação de grupos de pressão na tramitação do projeto de lei de biossegurança. Revista de Informação Legislativa, 43(169), pp.161-188.

West, W.F., 2004. Formal Procedures, Informal Processes, Accountability, and Responsiveness in Bureaucratic Policy Making: An Institutional Policy Analysis. Public Administration Review, 64(1), pp.66-80. DOI: 10.1111/j.1540-6210.2004.00347.x

2005. Administrative Rulemaking: An Old and Emerging Literature. Public Administration Review, 65(6), pp.655-668. DOI: $10.1111 / \mathrm{j} .1540-6210.2005 .00495 . x$

Yackee, S., 2005. Sweet-Talking the Fourth Branch: The Influence of Interest Group Comments on Federal Agency Rulemaking. Journal of Public Administration Research and Theory, 16(1), p.103-124. DOI: 10.1093/jopart/mui042

\section{Outras fontes}

ABAP, 2008. Números Oficiais da Indústria da Comunicação e seu Impacto na Economia Brasileira: 2008. Disponível em: http://www.abapnacional.com.br/images/publicacoes/abap_ibge_web.pdf. Acesso em: 11 fev 2016.

ABIA, 2010. Indústria da Alimentação - Principais Indicadores Econômicos. Disponível em: http://www.abia.org.br/anexos/FichaTecnica.pdf. Acesso em: 11 fev 2016.

Brasil, 1988. Constituição da República Federativa do Brasil de 1988. 1990. Código de Defesa do Consumidor. Dispõe sobre a proteção do consumidor e dá outras providências. Brasília, 11 set.

1999. Lei $n^{\circ}$ 9.882. Dispõe sobre o processo e julgamento da arguição de descumprimento de preceito fundamental, nos termos do $\S 1^{\circ}$ do art. 102 da Constituição Federal. Brasília, 3 dez.

2001. Altera dispositivos das Leis $n^{\circ}$ 9.782, de 26 de janeiro de 1999, que define o Sistema Nacional de Vigilância Sanitária e cria a Agência Nacional de Vigilância Sanitária, e nº 6.437, de 20 de agosto de 1977, que configura infrações à legislação sanitária federal e estabelece as sanções respectivas, e dá outras providências. Medida Provisória $\mathrm{n}^{\circ}$ 2.190-34, de 2001. Brasília: Ministério da Saúde.

2005. $R D C n^{\circ} 73 / 2005$. Institui grupo de trabalho para discutir proposta de regulação da publicidade de alimentos. Brasília: Ministério da Saúde.

,2006a. A saúde pública e a regulamentação da publicidade de alimentos. Brasília: Ministério da Saúde. Disponível em: http://189.28.128.100/nutricao/docs/geral/regulamentaPublicidadeAlimentos.pdf. Acesso em: 12 fev 2016.

2006b. Consulta Pública $n^{\circ} 71$, de 10 de novembro de 2006. Diário Oficial da União, 13 nov.

2007. Regulamentação da propaganda de alimentos no Brasil. Brasília: Ministério da Saúde. Disponível em http://www.anvisa.gov.br/propaganda/cp71_propaganda_alimentos.pdf. Acesso em: 12 fev 2016.

2010. Resolução da Diretoria Colegiada (RDC $n^{\circ}$ 24), de 15 de junho de 2010. Dispõe sobre a regulação da publicidade de alimentos. Diário Oficial da União, 29 jun. 
2012. Portaria $n^{\circ}$ 422, de 16 de março de 2012. Altera o Regimento Interno da Anvisa. Brasília: Agência Nacional de Vigilância Sanitária.
Grupo de Mídia
São Paulo,
2011.
Mídia
Dados
Brasil
2011.
Disponível
em:

http://midiadados.digitalpages.com.br/home.aspx?edicao=3. Acesso em: 12 fev 2016.

\begin{abstract}
This article analyzes the political action of business interest groups throughout the process of food propaganda regulation triggered by the National Health Surveillance Agency (Anvisa) in 2005. The main objectives were to describe the strategies and political articulations of these groups in order to assess whether its action has been successful in minimizing or overturning the controversial and conflicting regulation proposed by the agency, which effects would affect directly private sector activities. The study enclosed a detailed follow-up of each stage of the decision-making process, seeking to observe which political arenas are activated by these groups in order to accomplish its goals. For the conduction of this research, we have done a comprehensive examination of the documents related to the proposed regulation, which were produced by the three branches of government and the interest groups, and in-depth interviews with the main political players involved in this issue. The analysis made clear that business groups, reflecting their distinct political and economic resources, have access to many political arenas, such as Anvisa, National Congress, Judiciary and the Attorney General, which was a decisive actor in the political process herein studied. We also found evidences that the pressure exerted by business groups was able to mitigate, to a large extent, Anvisa's regulation, as the rule was considerably altered from the public comment period in 2006 until its promulgation in 2010. Nevertheless, we were able to observe that, despite the irresistible economic power of the two affected sectors, food and advertising industry, its political action was not able to prevent Anvisa from promulgating in 2010 a softer version of the regulation, which shows us the relative political autonomy of the agency. Finally, alterations in the structure and in the command of Anvisa in 2012, which are aligned with business interests, indicate deeper changes in the agency, which seem to have redefined the very bases of the relationship with businessmen.
\end{abstract}

KEYWORDS: lobbying; interest groups; Anvisa; regulatory agencies; food publicity regulation.

This is an Open Access article distributed under the terms of the Creative Commons Attribution Non-Commercial License which permits unrestricted non-commercial use, distribution, and reproduction in any medium provided the original work is properly cited. 